Research Article

\title{
Corn Response Across Plant Densities and Row Configurations for Different Moisture Environments
}

\author{
Kipling S. Balkcom (D) ${ }^{1}$ and Kira L. Bowen ${ }^{2}$ \\ ${ }^{1}$ USDA-ARS, National Soil Dynamics Laboratory, 411 S. Donahue Dr., Auburn, AL 36832-3439, USA \\ ${ }^{2}$ Department of Entomology and Plant Pathology, 209 Rouse Bldg., Auburn University, Auburn, AL 36849-5412, USA
}

Correspondence should be addressed to Kipling S. Balkcom; kip.balkcom@ars.usda.gov

Received 31 May 2019; Accepted 23 November 2019; Published 5 March 2020

Academic Editor: Allen Barker

Copyright (C) 2020 Kipling S. Balkcom and Kira L. Bowen. This is an open access article distributed under the Creative Commons Attribution License, which permits unrestricted use, distribution, and reproduction in any medium, provided the original work is properly cited.

\begin{abstract}
Corn (Zea mays L.) production in the Southeast can be negatively impacted by erratic summer rainfall and drought-prone, coarsetextured soils, but irrigation combined with conservation tillage and cover crops may support greater plant densities arranged in different row configurations to improve yield. We examined five site-years of data across two soil types in Alabama to compare corn yields in a conservation system across three plant densities for single- and twin-row configurations in dryland and irrigated moisture regimes. Treatments were arranged with a split plot treatment restriction in a RCB design with three replications. Main plots were irrigation level (no irrigation and irrigation), and subplots were a factorial arrangement of three plant densities (5.9, 7.4, and 8.9 plants $\mathrm{m}^{-2}$ ) and row configurations (single and twin). A moisture environment (low and moderate) variable, defined by growing season rainfall, was used to average over site-years. In general, irrigation in the moderate-moisture environment improved each measured variable (plant height, stover yield, corn yield, and test weight) and decreased grain $\mathrm{N}$ concentration and aflatoxin levels compared to the low-moisture environment with no irrigation. Benefits of increased rainfall and irrigation to reduce soil moisture stress across drought-prone soils were evident. Pooled results across all site-years indicated no yield response as plant density increased, but greater yields were observed with the greatest plant densities in the moderate-moisture environments. No advantage for twin-row corn production was observed across five site-years in Alabama, which indicates either row configuration can be successfully adopted.
\end{abstract}

\section{Introduction}

Sporadic summer rainfall combined with coarse-textured soils across the Southeast can limit corn production. Moisture deficits that occur during corn pollination can be particularly damaging to corn yields [1-3]. Increased aflatoxin production by Aspergillus flavus has also been associated with high temperatures and low average rainfall amounts during the silking to the late dough stage of corn development in southern production areas [4-6]. This suggests that timing of moisture deficits may be more important than season-long moisture deficits [7]. The uncertainty associated with experiencing favorable growing conditions for corn across the Southeast has prompted some growers to eliminate corn production from their operations.
Endale et al. [3] attributed the decline in southeastern corn production to producers voluntarily limiting planting to avoid risk of financial loss that may be due to unreliable yields and/or aflatoxin contamination.

One production practice that may offset limitations of soils with low water holding capacities for corn production is a conservation system that employs both conservation tillage and cover crops. Cover crops used in conjunction with conservation tillage can enhance soil physical properties, although benefits may be site specific [8,9]. Degraded Ultisols, prevalent across the Southeast, typically respond favorably to reduced surface tillage that promotes residue retention on the soil surface. Increases in organic matter and improvements in soil structure lead to improved infiltration, which potentially increases plant available water $[10,11]$. For 
example, Edwards et al. [12] attributed higher soybean (Glycine max L.) yields to moisture conservation by surface mulch present in strip tillage or no tillage. Strip tillage is designed to disrupt the soil beneath the crop row with minimal surface disturbance across the row middles, while no tillage is a form of conservation tillage that maximizes surface residue retention compared to conventional tillage [13].

Soil moisture conservation benefits associated with these tillage systems may help to overcome yield-limiting drought periods that occur during critical growth stages (i.e., reproductive phase) attributed to erratic seasonal rainfall distribution across soils with low water holding capacities [14]. Endale et al. [3] reported no tillage with a rye cover crop and poultry litter as the $\mathrm{N}$ source improved corn yields over a $5 \mathrm{yr}$ period when rainfall ranged from 20 to $95 \%$ of optimum during the tasseling to early dough stage based on $70 \mathrm{yr}$ daily rainfall records. These soil moisture conservation benefits are usually promoted for dryland crop production, but the benefits are also effective for irrigated producers to improve irrigation efficiency $[3,10]$. Southeastern corn growers with the ability to cost effectively implement irrigation on their farms can expect yield increases $[2,15]$. In addition, irrigation can also help to minimize aflatoxin contamination as part of an integrated aflatoxin management strategy $[16,17]$.

Conservation tillage, cover crops, and irrigation should improve corn yield potential across the Southeast. The favorable season-long soil moisture conditions that are possible by combining all three practices may also support yield increases through greater plant densities. Reducing row spacings can increase plant densities, which creates more equidistant plant spacing to reduce competition among plants for light, nutrients, and water [18]. Fulton [19] indicated greater plant densities produced higher yields compared to low plant densities under adequate soil moisture conditions. However, there is a point when competition for resources among plants will produce a yield decline. The point where the relationship between row spacing and plant population are optimized differs with cultivar and environment [20]. For example, Tollenaar [21] found that recently released corn hybrids, with erect leaf architecture that improves light interception, allow these hybrids to better withstand stresses compared to older hybrids.

Agronomically, narrow rows may be beneficial for corn production, but narrow rows are not easily adopted due to required changes related to field operations (i.e., tillage, planting, and harvesting) [2]. A twin-row configuration has been proposed to minimize equipment modifications, while preserving advantages of narrow rows $[2,22]$. Karlen and Camp [2] reported an average yield increase for twin-row corn of $640 \mathrm{~kg} \cdot \mathrm{ha}^{-1}$ compared to single rows with irrigation using conventional tillage across Atlantic Coastal Plain soils. However, Balkcom et al. [23] reported no consistent yield advantage for twin-row corn with conservation tillage and a cover crop across sandy loam and silt loam soils in Alabama. Balkcom et al. [23] also noted that soil moisture may have limited twin-row corn production because no supplemental irrigation was provided. The researchers speculated irrigation was necessary for a consistent twin-row yield advantage. Therefore, our objective was to compare conservation tillage corn yield potential across three plant densities for single- and twin-row configurations in dryland and irrigated moisture regimes.

\section{Materials and Methods}

Field experiments were conducted at the Field Crops Unit of the E.V. Smith Research Center (EVS) near Shorter, AL $\left(32^{\circ} 25^{\prime} 19.53^{\prime \prime} \mathrm{N} ; 85^{\circ} 53^{\prime} 20.13^{\prime \prime} \mathrm{W}\right)$ during the 2011,2012 , and 2014 growing seasons and the Tennessee Valley Research and Extension Center (TVS) in Belle Mina, AL ( $34^{\circ} 41^{\prime} 27.57^{\prime \prime}$ $\mathrm{N} ; 86^{\circ} 53^{\prime} 01.80^{\prime \prime} \mathrm{W}$ ) during the 2012 and 2013 growing seasons. Soil types at each location corresponded to Marvyn loamy sand (fine-loamy, kaolinitic, thermic Typic Kandiudult) at EVS and Decatur silt loam (fine, kaolinitic, thermic Rhodic Paleudult) at TVS.

The experimental design was a split plot treatment restriction in a randomized complete block design with three replications. Main plots (7.3 m $\times 73.2 \mathrm{~m}$-EVS; $23.8 \mathrm{~m} \times 18.3 \mathrm{~m}$-TVS) consisted of irrigation and no irrigation while subplots were a factorial combination of corn plant densities representing low $\left(5.9\right.$ plants $\mathrm{m}^{-2} ; 23,888$ plants $\mathrm{ac}^{-1}$ ), medium (7.4 plants $\mathrm{m}^{-2} ; 29,962$ plants $\mathrm{ac}^{-1}$ ), and high $\left(8.9\right.$ plants $\mathrm{m}^{-2} ; 36,035$ plants $\left.\mathrm{ac}^{-1}\right)$ plant densities and row configurations (single vs. twin). Subplot dimensions were $3.7 \mathrm{~m} \times 12.2 \mathrm{~m}$ for EVS and $3.0 \mathrm{~m} \times 11.9 \mathrm{~m}$ for TVS. At EVS, irrigation levels were achieved with a three-section lateral irrigation system that allowed one-half of each section to be randomly selected for no irrigation by blocking nozzles to create an irrigated and dryland section underneath each section of the lateral. At TVS, each subplot could be irrigated, depending on treatment with four sprinkler nozzles located in each corner of each subplot that were aligned to uniformly irrigate specific plots to create the irrigated and nonirrigated main plots. At both locations, all plots were irrigated approximately every $7 \mathrm{~d}$, depending on rainfall received and judgement of local staff. This irrigation approach is a common strategy adopted by growers in the region and commonly used in research for general irrigation. Minimum single irrigation application amounts corresponded to $\sim 20 \mathrm{~mm}$ at each location to prevent surface runoff. A single hybrid, DKC 64-69 ${ }^{\circledR}$ (Dekalb Genetics Corporation; Dekalb, IL), was chosen for both locations and all years of the experiment.

Each experimental location consisted of a conservation system that included a rye (Secale cereale L.) cover crop established with a no-till drill and seeded at $100 \mathrm{~kg} \cdot \mathrm{ha}^{-1}$ each fall, prior to corn planting. Rye was fertilized with $34 \mathrm{~kg}$ $\mathrm{N} \cdot \mathrm{ha}^{-1}$ each year as $\mathrm{NH}_{4} \mathrm{NO}_{3}(33-0-0-10)$ to enhance biomass production. The cover crop was terminated each year with glyphosate [isopropylamine salt of $\mathrm{N}$-(phosphonomethyl) glycine] at least $2 \mathrm{wk}$ prior to corn planting. Biomass measurements were determined immediately prior to chemical termination by cutting all aboveground tissue from two random $0.25 \mathrm{~m}^{2}$ areas within each plot, drying at $55^{\circ} \mathrm{C}$ for $72 \mathrm{~h}$, and weighing. Cover crop termination timing was not based on the growth stage, but corresponded to the 
anticipated corn planting date to allow maximum biomass production and soil moisture recharge by natural rainfall $[24,25]$. No irrigation was applied at either location each year when the cover crop was present. All relevant information pertaining to cover crops is summarized in Table 1.

Approximately $2 \mathrm{~d}$ prior to corn planting, all plots at EVS were in-row subsoiled 35 to $40 \mathrm{~cm}$ deep with a KMC Generation I Rip-Strip (Kelly Manufacturing Co., Tifton, GA). This strip tillage configuration consisted of a coulter, shank, and pneumatic press wheels. At TVS, corn was seeded directly into the soil without any prior tillage. These tillage scenarios were representative of tillage practices for each location, prior to planting corn, based on soil type.

At EVS, single rows were seeded with a John Deere 1700 MaxEmerge Plus (Deere \& Co., Moline, IL) planter equipped with Dawn (Dawn Equipment Co., Sycamore, IL) row cleaners. Twin rows were seeded with a Monosem (Monosem Inc., Edwardsville, KS) twin-row planter that had a coulter mounted in front of each individual row. Single- and twin-row configurations were seeded with a Great Plains 1510P Precision Three-Point (Great Plains Manufacturing Inc., Salina, KS) planter at TVS. In the twin-row configuration at both locations, individual plant densities for both rows of the twin-row configuration were reduced by onehalf to match the equivalent plant density of the single-row configuration. Row spacing at EVS was $91 \mathrm{~cm}$ and $76 \mathrm{~cm}$ at TVS. The Great Plains 1510P Precision Planter did not have the capability to plant rows $>76 \mathrm{~cm}$; therefore, a single planter could not be used at both locations. Farm equipment (i.e., tractors, sprayers, and combines) could not be altered for both row spacings; therefore, available existing equipment was utilized at each location to manage each experiment. Dates that correspond to select cultural practices including planting, sidedress $\mathrm{N}$, irrigation, and harvesting for each site-year are summarized in Table 2.

Every year, composite soil samples ( 10 samples) were randomly collected in the fall across blocks with a $2.54 \mathrm{~cm}$ soil probe to a depth of $30 \mathrm{~cm}$ to evaluate soil test ratings for $\mathrm{P}, \mathrm{K}$, and soil $\mathrm{pH}$. Preplant applications of $\mathrm{P}, \mathrm{K}$, and lime were applied as necessary at each location to ensure soil test ratings were considered "high" based on Alabama Experiment Station recommendations for corn [26]. Nitrogen fertilizer was surface-applied as a starter application at $56 \mathrm{~kg}$ $\mathrm{N} \cdot \mathrm{ha}^{-1}$ in a granular form, either as 17-17-17 at EVS or $\mathrm{NH}_{4} \mathrm{NO}_{3}$ (33-0-0-10) at TVS, prior to planting. The remaining $\mathrm{N}\left(185 \mathrm{~kg} \cdot \mathrm{ha}^{-1}\right)$ was injected at sidedress as $28 \%$ (EVS) or $32 \%$ (TVS) urea-ammonium-nitrate.

Plant heights were measured from the ground to the uppermost node of the plant below the tassel at physiological maturity from 10 randomly selected plants in each plot. Immediately prior to harvest, corn stover samples were collected from each subplot by clipping all aboveground plant material from a $0.91 \mathrm{~m}^{2}$ (EVS) and $0.76 \mathrm{~m}^{2}$ (TVS) area. Different sampling area sizes were required due to different row spacings used at each location. All corn stover (cobs, stalks, leaves, and husks) was dried at $55^{\circ} \mathrm{C}$ for $72 \mathrm{~h}$ prior to weighing.

Corn was harvested each year using a mechanical combine. All grain yields were adjusted to a moisture content of $155 \mathrm{~g} \cdot \mathrm{kg}^{-1}$. A subsample of grain was obtained from each plot and dried at $55^{\circ} \mathrm{C}$ for $72 \mathrm{~h}$. A portion of the grain subsample was ground to pass through a $2 \mathrm{~mm}$ screen with a Wiley mill (Thomas Scientific, Swedesboro, NJ) and then ground further to pass through a $1 \mathrm{~mm}$ screen with a Cyclone grinder (Thomas Scientific, Swedesboro, NJ). Each subsample following grinding was analyzed for total $\mathrm{N}$ by dry combustion on a LECO TrueSpec-CN analyzer (Leco Corp., St. Joseph, MI). The remaining portion of the subsample was used to determine test weights by weighing grain contained in a standard volumetric cup designed by Seedburo Equipment Company (Des Plaines, IL).

A second subsample of grain was also collected for aflatoxin assays. This subsample was also ground with a Wiley mill to pass through a $6 \mathrm{~mm}$ screen. Ten $\mathrm{g}$ of the ground corn sample was assayed for aflatoxin using the Veratox test (Neogen Corp., Lansing, MI). This enzyme-linked immunosorbent assay (ELISA) is valid for $5-50 \mathrm{ppb}$ total aflatoxins. If the assay indicated levels $>50 \mathrm{ppb}$, the extraction was diluted and assayed again. A minimum of $10 \%$ of the samples were assayed twice to confirm aflatoxin content.

2.1. Statistical Analysis. Data from measured variables (plant density, plant height, stover yield, grain yield, test weight, grain $\mathrm{N}$, and aflatoxin content) that did not fit a normal distribution were rank-transformed for means separation. Aflatoxin content was transformed as $(\ln (\mathrm{ppb}+1))$ prior to analysis. Generalized linear mixed model analyses using PROC GLIMMIX (SAS 9.4, SAS Institute, Cary, NC) were conducted on all measured variables. In preliminary analyses, site-year, irrigation, row pattern, and plant density were fixed effects in the model while block and block $\times$ irrigation were random effects. Nontransformed means of variables are presented. Factor effects were determined to be significant when $P<0.05$.

\section{Results and Discussion}

3.1. Climate Data. Rainfall totals for each corn growing season ranged from $381 \mathrm{~mm}$ to $675 \mathrm{~mm}$ across the five siteyears examined in this study (Table 3). At EVS, rainfall totals for all three years were below the $10 \mathrm{y}$ average for the location, although 2014 was similar $( \pm 5 \%)$ to the $10 \mathrm{y}$ average (Table 3). At TVS, a dry (2012) and wet (2013) year was observed compared to the $10 \mathrm{y}$ average for the location (Table 3). Rainfall distribution was variable across site-years, which is also highlighted by monthly distribution of rainfall (Table 3). For example, 2011 at EVS was much drier based on rainfall totals compared to 2012 at EVS; however, more irrigation was applied in 2012 as compared to 2011 (Table 3). In 2011, rainfall for the month of July was $143 \%$ higher than the corresponding month in 2012 at EVS. The wet July of 2011 negated the need for late season irrigation at EVS compared to 2012, which reduced total irrigation amounts.

The variability in rainfall observed across locations, despite irrigation, created different moisture environments. Preliminary analyses indicated site-year affected $(P<0.0001)$ all measured variables (Table 4 ), but two site-years stood out 
TABLE 1: Planting dates, $\mathrm{N}$ fertilizer application dates, termination dates, and aboveground biomass measured for a rye ("Wrens Abruzzi") cover crop at five site-years during the 2011 to 2014 growing seasons across northern and central Alabama.

\begin{tabular}{|c|c|c|c|c|}
\hline Site-year $^{\mathrm{a}}$ & Planting date & $\mathrm{N}$ fertilizer date & Termination date & Biomass $\left(\mathrm{kg} \cdot \mathrm{ha}^{-1}\right)$ \\
\hline EVS 2011 & November 3, 2010 & February 16, 2011 & March 23, 2011 & $2300(130)^{\mathrm{b}}$ \\
\hline EVS 2012 & November 7, 2011 & February 24, 2012 & March 21, 2012 & $3435(175)$ \\
\hline EVS 2014 & December 16, 2013 & February 18, 2014 & March 27, 2014 & $835(40)$ \\
\hline TVS 2012 & October 26, 2011 & December 9, 2011 & March 19, 2012 & $3365(190)$ \\
\hline TVS 2013 & November 16, 2012 & March 3, 2013 & March 28, 2013 & $2190(155)$ \\
\hline
\end{tabular}

${ }^{\mathrm{a}}$ EVS, E.V. Smith Research Center; TVS, Tennessee Valley Research and Extension Center. ${ }^{\mathrm{b}}$ Standard error.

TABLE 2: Dates for select cultural practices that include planting, sidedress N, irrigation, and harvest at five site-years during the 2011 to 2014 growing seasons across northern and central Alabama.

\begin{tabular}{|c|c|c|c|c|c|}
\hline \multirow{2}{*}{ Field operation } & \multicolumn{3}{|c|}{$\mathrm{EVS}^{\mathrm{a}}$} & \multicolumn{2}{|c|}{ TVS $^{\mathrm{b}}$} \\
\hline & 2011 & 2012 & 2014 & 2012 & 2013 \\
\hline Planting date & April 4 & April 2 & April 13 & April 4 & April 13 \\
\hline Sidedress N & April 27 & May 7 & May 20 & May 11 & May 24 \\
\hline \multicolumn{6}{|l|}{ Irrigation events ${ }^{c}$} \\
\hline $1^{\text {st }}$ & April 26 & April 25 & July 1 & May 23 & May 30 \\
\hline $2^{\text {nd }}$ & May 10 & April 30 & July 14 & May 24 & June 13 \\
\hline $3^{\text {rd }}$ & May 27 & May 27 & July 31 & May 29 & June 18 \\
\hline $4^{\text {th }}$ & June 3 & June 20 & August 12 & June 12 & June 20 \\
\hline $5^{\text {th }}$ & June 13 & June 29 & & June 14 & June 25 \\
\hline $6^{\text {th }}$ & June 15 & July 18 & & June 19 & June 27 \\
\hline $7^{\text {th }}$ & & & & June 21 & July 2 \\
\hline $8^{\text {th }}$ & & & & June 26 & July 18 \\
\hline $9^{\text {th }}$ & & & & June 28 & July 30 \\
\hline $10^{\text {th }}$ & & & & July 3 & \\
\hline $11^{\text {th }}$ & & & & July 5 & \\
\hline $12^{\text {th }}$ & & & & July 26 & \\
\hline $13^{\text {th }}$ & & & & August 7 & \\
\hline $14^{\text {th }}$ & & & & August 9 & \\
\hline Harvest & August 16 & August 27 & September 2 & August 30 & September 12 \\
\hline
\end{tabular}

${ }^{\mathrm{a}}$ EVS, E.V. Smith Research Center. ${ }^{\mathrm{b}}$ TVS, Tennessee Valley Research and Extension Center. ${ }^{\mathrm{c}}$ Each irrigation event $(20 \mathrm{~mm})$ was initiated every $7 \mathrm{~d}$ unless rainfall received exceeded $25 \mathrm{~mm}$.

from the others in that season-long rain amounts were low (<480 mm; EVS11 and TVS12; Table 3). Further analyses used two groups of environments based on rainfall to distinguish between moisture environments; EVS11 and TVS12 were considered "low", and the remaining three (EVS12, EVS14, and TVS13) were considered "moderate."

3.2. Plant Heights and Stover Yield. Moisture environment $(P<0.0001)$ and irrigation $(P=0.0179)$ each affected plant height (Table 5). The moderate-moisture environment produced plants $45 \%$ taller compared to the low-moisture environment, while irrigation produced plants $8 \%$ taller compared to no irrigation (data not shown). The moisture environment $\times$ irrigation interaction $(P=0.0330$; Table 5$)$ was due to similar plant heights with or without irrigation for the moderate-moisture environment, while plant height in the low-moisture environment was $16 \%$ shorter for no irrigation compared to irrigation (Table 6). Plant height in low-moisture environments was $25 \%$ and $37 \%$ shorter than in moderate-moisture environments with and without irrigation, respectively (Table 6 ). The moisture environment $\times$ row pattern interaction $(P=0.0126$; Table 5) indicated plant height averaged $45 \%$ taller in the moderate- moisture environment compared to the low-moisture environment, regardless of row pattern (data not shown).

Irrigation ( $P=0.0005$; Table 5$)$ improved stover yield by $27 \%$ compared to no irrigation (data not shown). However, the moisture environment $\times$ irrigation interaction $(P=0.0083$; Table 5$)$ indicated stover yield was greatest in the low-moisture environment with irrigation and lowest in the low-moisture environment with no irrigation; stover in moderate-moisture environments was intermediate (Table 6). The greatest stover production measured in the low-moisture environment with irrigation indicates that rainfall and irrigation timing may have been optimal to maximize stover production.

Irrigation, regardless of moisture environment, tended to favor taller plants with more stover biomass production for the hybrid used in this experiment. In the low-moisture environments, plant height correlated positively with stover production (Table 7). Blanco-Canqui and Lal [27] reported positive correlations between corn plant heights at silking and soil water content. Mourtzinis et al. [28] reported that plant height has been used as a critical variable in previous statistical models to assess corn yields. However, yield prediction relationships are improved by including other morphological measurements, agronomic information, and climate data [28]. 
TABLE 3: Distribution by month and totals for rainfall and irrigation at five site-years during the 2011 to 2014 growing seasons across northern and central Alabama.

\begin{tabular}{|c|c|c|c|c|c|c|c|}
\hline \multirow{2}{*}{ Month } & \multicolumn{4}{|c|}{$\mathrm{EVS}^{\mathrm{a}}$} & \multicolumn{3}{|c|}{ TVS $^{\mathrm{b}}$} \\
\hline & 2011 & 2012 & 2014 & $10 \mathrm{y}$ avg. ${ }^{\mathrm{c}}$ & 2012 & 2013 & $10 \mathrm{y}$ avg. ${ }^{\mathrm{c}}$ \\
\hline \multicolumn{8}{|c|}{ Rainfall $\mathrm{mm}$} \\
\hline April & 48 & 24 & 130 & 79 & 41 & 108 & 125 \\
\hline May & 56 & 176 & 114 & 108 & 80 & 165 & 108 \\
\hline June & 57 & 77 & 107 & 97 & 34 & 85 & 77 \\
\hline July & 204 & 84 & 89 & 131 & 222 & 250 & 142 \\
\hline August & 16 & 133 & 75 & 118 & 87 & 56 & 77 \\
\hline September & $0^{\mathrm{d}}$ & 0 & 0 & 0 & 0 & 11 & 4 \\
\hline Total & 381 & 494 & 515 & 533 & 464 & 675 & 533 \\
\hline \multicolumn{8}{|c|}{ Irrigation $\mathrm{mm}$} \\
\hline April & 10 & 71 & & & & & \\
\hline May & 42 & 41 & & & 44 & 13 & \\
\hline June & 64 & 81 & & & 102 & 95 & \\
\hline July & & 81 & 85 & & 44 & 51 & \\
\hline August & & & 23 & & 25 & & \\
\hline Total & 116 & 274 & 108 & & 215 & 159 & \\
\hline
\end{tabular}

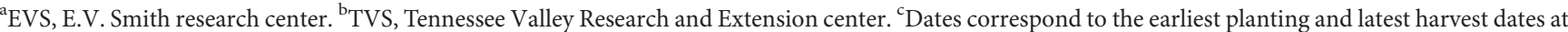
each location for the 2004 to 2014 time period. " "0" represents no rainfall documented because the harvest date occurred in August or no rainfall was received during September, prior to the harvest.

TABLE 4: Overall averages for plant height, stover yield, corn yield, test weight, grain $\mathrm{N}$ concentration, and aflatoxin content at five site-years during the 2011 to 2014 growing seasons across northern and central Alabama.

\begin{tabular}{|c|c|c|c|c|c|c|}
\hline Site-year & Plant height, $\mathrm{cm}$ & Stover, $\mathrm{kg} \cdot \mathrm{ha}^{-1}$ & Yield, kg.ha ${ }^{-1}$ & Test weight & Grain $\mathrm{N}, \mathrm{g} \cdot \mathrm{kg}^{-1}$ & Aflatoxin \\
\hline EVS 2011 & $162.2 \mathrm{e}$ & $7648.4 \mathrm{~d}$ & $3130 d$ & $60.8 \mathrm{a}$ & $15.2 \mathrm{a}$ & $17.62 \mathrm{a}$ \\
\hline EVS 2012 & $253.7 \mathrm{a}$ & $\mathrm{ND}^{\mathrm{a}}$ & $11445 b$ & $58.4 \mathrm{c}$ & $12.5 \mathrm{c}$ & $24.33 \mathrm{a}$ \\
\hline EVS 2014 & $229.1 b$ & $9459.9 c$ & $11183 b$ & $60.8 \mathrm{a}$ & $12.4 \mathrm{c}$ & $2.97 \mathrm{~b}$ \\
\hline TVS 2012 & $158.9 \mathrm{e}$ & $14309 a$ & $7294 c$ & $58.9 c$ & $15.3 \mathrm{a}$ & $27.58 \mathrm{a}$ \\
\hline TVS 2013 & $215.9 c$ & $11184 b$ & $15061 \mathrm{a}$ & $59.8 \mathrm{~b}$ & $13.1 \mathrm{~b}$ & $3.53 b$ \\
\hline
\end{tabular}

${ }^{\mathrm{a}}$ Not determined; dry weights were not collected prior to grinding.

TABle 5: $P$ values from a general linear mixed model analysis for specific treatments over five site-years during the 2011 to 2014 growing seasons across northern and central Alabama.

\begin{tabular}{|c|c|c|c|c|c|c|c|}
\hline Effect & $\mathrm{df}$ & Plant height & Stover yield $^{\mathrm{a}}$ & Yield & Test weight & Grain N & Aflatoxin \\
\hline Environment $(\mathrm{ME})^{\mathrm{b}}$ & 9 & $<0.0001^{c}$ & 0.8571 & $<0.0001$ & 0.6502 & $<0.0001$ & $<0.0001$ \\
\hline Irrigation (I) & 1 & 0.0179 & 0.0005 & $<0.0001$ & 0.8858 & 0.0001 & 0.0212 \\
\hline $\mathrm{ME} \times \mathrm{I}$ & 9 & 0.0330 & 0.0083 & 0.0422 & 0.0159 & 0.0083 & 0.0498 \\
\hline Row pattern (RP) & 1 & 0.7984 & 0.2163 & 0.3999 & 0.1086 & 0.2771 & 0.4824 \\
\hline $\mathrm{ME} \times \mathrm{RP}$ & 9 & 0.0126 & 0.4597 & 0.3993 & 0.9476 & 0.8240 & 0.3996 \\
\hline $\mathrm{I} \times \mathrm{RP}$ & 1 & 0.4926 & 0.6485 & 0.7227 & 0.6243 & 0.5054 & 0.7913 \\
\hline $\mathrm{ME} \times \mathrm{I} \times \mathrm{RP}$ & 9 & 0.7957 & 0.9267 & 0.7841 & 0.3440 & 0.7331 & 0.5400 \\
\hline Population (P) & 2 & 0.8039 & 0.8286 & 0.5571 & 0.8000 & 0.0416 & 0.1225 \\
\hline $\mathrm{P} \times \mathrm{ME}$ & 18 & 0.2453 & 0.9691 & 0.3463 & 0.4508 & 0.5197 & 0.8758 \\
\hline $\mathrm{P} \times \mathrm{I}$ & 2 & 0.5393 & 0.8704 & 0.8412 & 0.8834 & 0.6799 & 0.8561 \\
\hline $\mathrm{P} \times \mathrm{ME} \times \mathrm{I}$ & 18 & 0.9848 & 0.8577 & 0.9470 & 0.9273 & 0.3391 & 0.8885 \\
\hline $\mathrm{P} \times \mathrm{RP}$ & 2 & 0.7517 & 0.9884 & 0.9546 & 0.8459 & 0.6785 & 0.9104 \\
\hline $\mathrm{P} \times \mathrm{ME} \times \mathrm{RP}$ & 18 & 0.6544 & 0.8433 & 0.8672 & 0.9495 & 0.7538 & 0.7111 \\
\hline $\mathrm{P} \times \mathrm{I} \times \mathrm{RP}$ & 2 & 0.7240 & 0.8480 & 0.6709 & 0.4135 & 0.5950 & 0.9686 \\
\hline $\mathrm{ME} \times \mathrm{I} \times \mathrm{RP} \times \mathrm{P}$ & 18 & 0.9677 & 0.9462 & 0.8353 & 0.9203 & 0.9971 & 0.7074 \\
\hline
\end{tabular}

${ }^{a}$ One site-year (E.V. Smith in 2012) was excluded from the analysis because dry weights for samples were not obtained. ${ }^{\mathrm{b}}$ Environment represents moisture environments where $<480 \mathrm{~cm}$ rainfall at two site-years (EVS11 and TVS12) were "low moisture" and other site-years were "moderate moisture." ${ }^{\mathrm{c} B o l d}$ values indicate significant differences $(P<0.05)$. 
TABLE 6: Average plant height, stover yield, yield, test weight, grain $\mathrm{N}$ concentrations, and aflatoxin content measured across irrigated and dryland treatments within low- and moderate- moisture environments for five site-years during the 2011 to 2014 growing seasons across northern and central Alabama.

\begin{tabular}{lccccccc}
\hline Effect & $\begin{array}{c}\text { Plant height, } \\
\mathrm{cm}\end{array}$ & $\begin{array}{c}\text { Stover yield, } \\
\mathrm{kg} \cdot \mathrm{ha}^{-1}\end{array}$ & $\begin{array}{c}\text { Yield, } \\
\mathrm{kg}^{-1 \mathrm{ha}^{-1}}\end{array}$ & $\begin{array}{c}\text { Test } \\
\text { weight }\end{array}$ & $\begin{array}{c}\text { Grain N, } \\
\mathrm{g}^{-k^{-1}}\end{array}$ & $\begin{array}{c}\text { Aflatoxin } \\
\mathrm{ppb}\end{array}$ & $\begin{array}{c}\text { Aflatoxin samples } \\
\geq 20 \mathrm{ppb}(\%)\end{array}$ \\
\hline Low ME ; irrigated & $174.9 \mathrm{~b}$ & $13249 \mathrm{a}$ & $8178 \mathrm{c}$ & $59.5 \mathrm{ab}$ & $14.7 \mathrm{~b}$ & $11.06 \mathrm{~b}$ & 36.1 \\
Moderate ME; irrigated & $233.7 \mathrm{a}$ & $10510 \mathrm{ab}$ & $13532 \mathrm{a}$ & $59.9 \mathrm{ab}$ & $12.6 \mathrm{c}$ & $3.66 \mathrm{c}$ & 22.2 \\
Low ME; dryland & $146.2 \mathrm{c}$ & $8708 \mathrm{c}$ & $2246 \mathrm{~d}$ & $60.0 \mathrm{a}$ & $15.7 \mathrm{a}$ & $32.24 \mathrm{a}$ & 75.0 \\
Moderate ME; dryland & $233.0 \mathrm{a}$ & $10044 \mathrm{~b}$ & $11504 \mathrm{~b}$ & $59.4 \mathrm{~b}$ & $12.7 \mathrm{c}$ & $4.10 \mathrm{c}$ & 24.0 \\
\hline
\end{tabular}

${ }^{a}$ Moisture environment.

TABLe 7: Spearman's rank correlation coefficients $(R), P$ values, and number of observations $(n)$ between plant height, stover yield, yield, grain $\mathrm{N}$ concentration, and aflatoxin values. Upper right cells are for the low-moisture environment; lower left cells are for the moderatemoisture environment.

\begin{tabular}{|c|c|c|c|c|c|}
\hline \multirow{2}{*}{ Moderate-moisture environment } & \multicolumn{5}{|c|}{ Low-moisture environment } \\
\hline & Plant height & Stover yield & Yield & Grain N & Aflatoxin \\
\hline \multirow{3}{*}{ Plant height } & $R$ & 0.2345 & 0.5063 & -0.5491 & -0.1834 \\
\hline & $P$ value & 0.0474 & $<0.0001$ & $<0.0001$ & 0.1231 \\
\hline & $n$ & 72 & 72 & 71 & 72 \\
\hline \multirow{3}{*}{ Stover yield } & -0.2220 & & 0.7176 & -0.3570 & -0.0738 \\
\hline & 0.0647 & & $<0.0001$ & 0.0022 & 0.5376 \\
\hline & 70 & & 72 & 71 & 72 \\
\hline \multirow{3}{*}{ Yield } & -0.4026 & 0.4410 & & -0.6251 & -0.2630 \\
\hline & $<0.0001$ & 0.0001 & & $<0.0001$ & 0.0256 \\
\hline & 106 & 70 & & 71 & 72 \\
\hline \multirow{3}{*}{ Grain $\mathrm{N}$} & -0.2430 & 0.3204 & 0.0284 & & 0.3817 \\
\hline & 0.0121 & 0.0061 & 0.7725 & & 0.0010 \\
\hline & 106 & 72 & 106 & & 71 \\
\hline \multirow{3}{*}{ Aflatoxin } & 0.4828 & 0.2025 & -0.1286 & 0.2337 & \\
\hline & $<0.0001$ & 0.0880 & 0.1889 & 0.0149 & \\
\hline & 106 & 72 & 106 & 108 & \\
\hline
\end{tabular}

Measurements of stover production can quantify differences in plant growth among treatment variables. Stover production estimates have gained importance recently due to the use of stover as a bioenergy source for biofuel production. Identifying harvestable amounts of corn stover that minimizes negative impacts on the soil has been a primary question in this area of research [29].

3.3. Yield. Moisture environment $(P<0.0001)$ and irrigation $(P<0.0001)$ each affected corn yield (Table 5$)$. The moderate-moisture environment increased corn yield $140 \%$, while irrigation increased corn yield $58 \%$, compared to the low-moisture environment and no irrigation, respectively (data not shown). Corn yield increases, across the Southeast, with sufficient rainfall amounts and/or irrigation during critical growth periods throughout the growing season are not surprising. Many southeastern soils are characterized as degraded Ultisols with coarse textures, poor structure, and low organic matter contents $(<1 \%)$, which contribute to limited soil water storage [30]. The moisture environment $\times$ irrigation interaction was significant $(P=0.0422$; Table 5) and corn yield was greatest in the moderatemoisture environment with irrigation compared to all other combinations (Table 6). Corn yield was $15 \%$ lower in the moderate-moisture environment without irrigation compared to with irrigation (Table 6). In the low-moisture environments, corn yield with irrigation was $3.6 \mathrm{x}$ greater than without irrigation (Table 6).

Yield was positively $(R=0.51, P<0.0001)$ correlated to plant height in the low-moisture environment, but negatively $(R=-0.40, P<0.0001)$ correlated in the moderatemoisture environment (Table 7). Regardless of moisture environment, yield was positively $(R>0.44, P<0.0001)$ correlated to stover production (Table 7 ). Plants with the greatest ability to intercept light (i.e., increased stover), although not always the tallest plants, produced the greatest yields. Reeves and Mullins [31] also reported cotton (Gossypium hirsutum L.) yields increased as the photosynthetic area of the plant increased.

No yield response to row pattern was observed, despite examining yield data between the two different moisture environments (Table 5). Balkcom et al. [23] had also observed a lack of corn yield response to row pattern across similar soil types in Alabama, but they attributed this to limited soil moisture despite using a conservation system. Potential soil moisture benefits associated with the conservation system did not produce greater twin-row yields compared to single rows. The limited ability to produce cover crop biomass preceding corn (Table 1), due to the early 
termination time required, could limit soil moisture conservation benefits of the system [32]. However, twin-row peanut (Arachis hypogea L.) production is popular across the Southeast $[13,33]$; therefore, corn growers should experience no yield reduction if they choose to use the same planter for corn and peanut production.

Plant density measurements collected 3 weeks after planting corresponded to 6.0 plants $\mathrm{m}^{-2}, 7.0$ plants $\mathrm{m}^{-2}$, and 8.9 plants $\mathrm{m}^{-2}$ for the low, medium, and high plant densities, respectively (data not shown). Plant densities examined in this study represent a wide range to encompass dryland producers and irrigated producers. However, plant density nor interactions with plant density had no effect on corn yield (Table 5). In general, as plant densities increase, corn yields increase, but once plant densities reach a certain point that varies with environment, yields will decline $[2,20]$.

Pooling data across all site-years and irrigation treatments indicated no statistical yield response associated with plant densities. No response to plant density does have implications for seed cost that may be significant at higher plant densities. Although there was not a significant yield response due to increases in plant density in the pooled data, greater yields were observed with greater densities for some site-years. Analysis of only the moderate-moisture environments showed that the greatest plant densities resulted in significantly greater yields than medium or lower densities. In the low-moisture environments, the greatest plant density had numerically lower yield than other planting densities. In the site-year with most restricted moisture (EVS 11), lower yields were noted with medium density than with low plant density, even with irrigation. These results support previous research that indicates nonlimiting soil moisture conditions must exist to support increased corn plant densities across coarse-textured soils of the Southeast [23].

Figure 1 shows rainfall and irrigation received across a time period that includes silking for the two site-years included in the low-moisture environment. Dry periods of $15 \mathrm{~d}$ that began on 28 May (Figure 1 (a)) and $23 \mathrm{~d}$ that began on 12 June (Figure 1(b)) illustrate corresponding irrigation amounts supplied during these periods. At TVS, the stationary sprinkler nozzles located in each plot enabled more frequent, timely irrigation applications compared to the lateral irrigation system used at EVS during extended dry periods.

3.4. Test Weight and Grain N Concentration. Test weight, an indicator of grain quality, was not affected by moisture environment or irrigation, but an interaction between moisture environment and irrigation $(P=0.0159)$ was observed (Table 5). No irrigation in the low-moisture environment produced a greater test weight than no irrigation in the moderate-moisture environment (Table 6). Test weights in the low and moderate-moisture environments with irrigation were intermediate of these values (Table 6). Economic differences associated with measured test weights were not calculated, but the small differences, although significant, were minimal compared to yield differences across moisture environments and irrigation levels.

Moisture environment $(P<0.0001)$ and irrigation $(P=0.0001)$ each affected grain $\mathrm{N}$ concentration (Table 5$)$. Grain N concentrations were 16\% less in the moderatemoisture environment compared to the low-moisture environment, while irrigation produced grain $\mathrm{N}$ concentrations $4 \%$ less than no irrigation (data not shown). Increased soil moisture, regardless of moisture environment or irrigation, is thought to increase corn growth and produce a dilution of grain $\mathrm{N}$ concentration present in the plant. Justes et al. [34] have described this phenomenon for wheat (Triticum aestivum L.), but the principle would also apply to corn. Plant density $(P=0.0416)$ also affected grain $\mathrm{N}$ concentration, but the differences were small. The low plant density produced grain $\mathrm{N}$ concentrations 3\% greater than grain $\mathrm{N}$ concentrations from the high plant density, while the medium density produced grain $\mathrm{N}$ concentrations intermediate of these levels (data not shown). The moisture environment $\times$ irrigation interaction $(P=0.0083$; Table 5$)$ was due to significantly decreased grain $\mathrm{N}$ with irrigation in the low-moisture environments while there was not an effect due to irrigation in the moderate-moisture environments (Table 6).

Regardless of moisture environment, grain $\mathrm{N}$ concentration was negatively correlated to plant height $(R>-0.24$, $P<0.0121)$. However, while grain $\mathrm{N}$ was negatively correlated to stover production in the low-moisture environment $(R=-0.35, \quad P=0.0022), \quad$ it was positively correlated ( $R=0.32, P=0.0061)$ with stover production in the moderate-moisture environment (Table 7). As noted previously, grain $\mathrm{N}$ is decreased with greater plant growth (reflected by stover quantity), which was substantially increased with irrigation in low-moisture environments (Table 6); however, in moderate-moisture environments, irrigation had little impact on stover quantity.

Estimates of grain $\mathrm{N}$ concentration are critical to determine grain $\mathrm{N}$ removal calculations necessary for calculating a $\mathrm{N}$ balance [35]. Although beyond the scope of this experiment, estimates of a $\mathrm{N}$ balance help determine optimal $\mathrm{N}$ fertilizer rates to maximize profits and minimize environmental $\mathrm{N}$ losses. Plant breeders' propensity to select hybrids for higher yields has created an unintended consequence of grain $\mathrm{N}$ concentrations decreasing over time [36]. As previously stated, the common explanation for this inverse relationship is a dilution effect, but Tenorio et al. [35] reported a weak, positive relationship between grain $\mathrm{N}$ concentration and yield representing numerous comparisons from the US North Central Region. This region represents a large corn production area of the US, but this relationship has not been examined extensively across other regions of the US, such as the Southeast.

3.5. Aflatoxin. Moisture environment $(P<0.0001)$ and irrigation $(P=0.0212)$ also affected aflatoxin levels (Table 5). Average aflatoxin content of corn from the moderatemoisture environments was $48 \%$ lower compared to the lowmoisture environment; $23.1 \%$ of moderate-moisture plot 


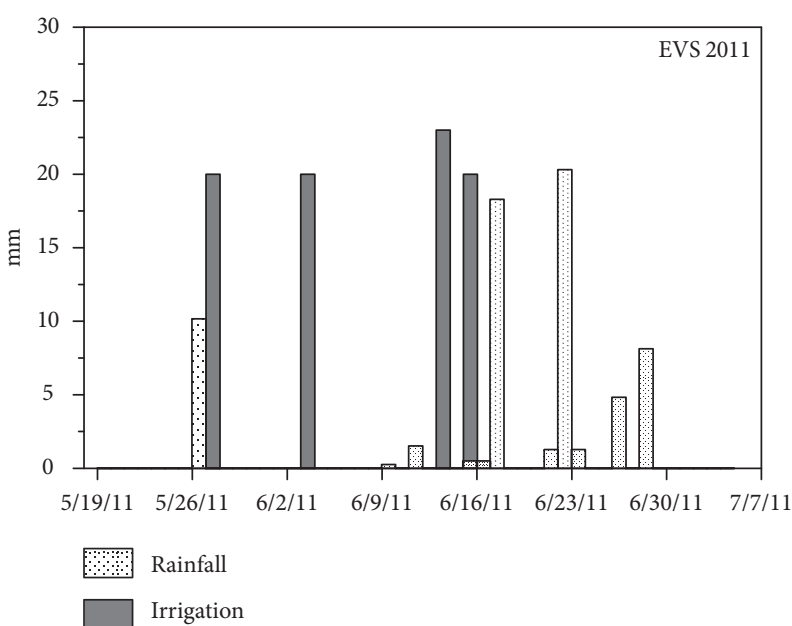

(a)

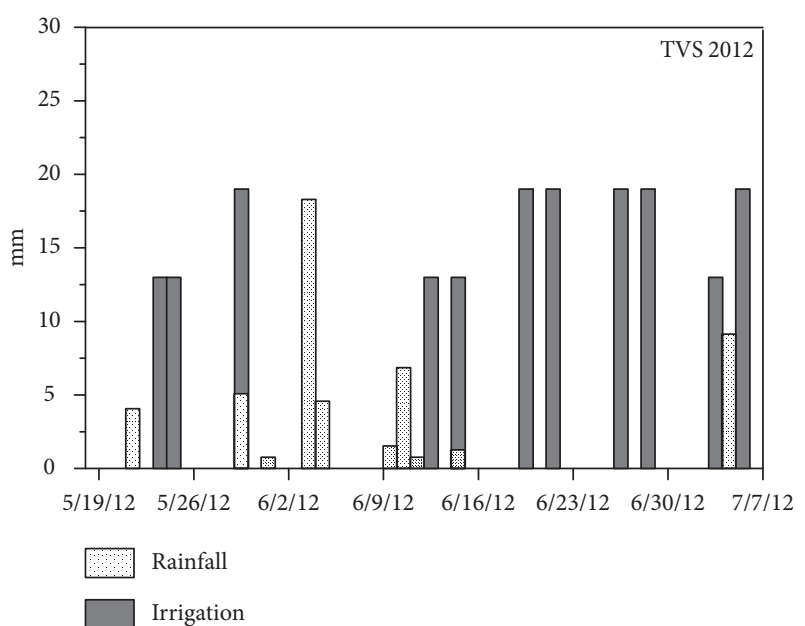

(b)

FIGURE 1: Rainfall and irrigation received at the low-moisture environments of EVS in 2011 (a) and TVS in 2012 (b) from May 19 to July 7 of each growing season that corresponds to the corn silking time period for all five site-years during the 2011 to 2014 growing seasons across northern and central Alabama.

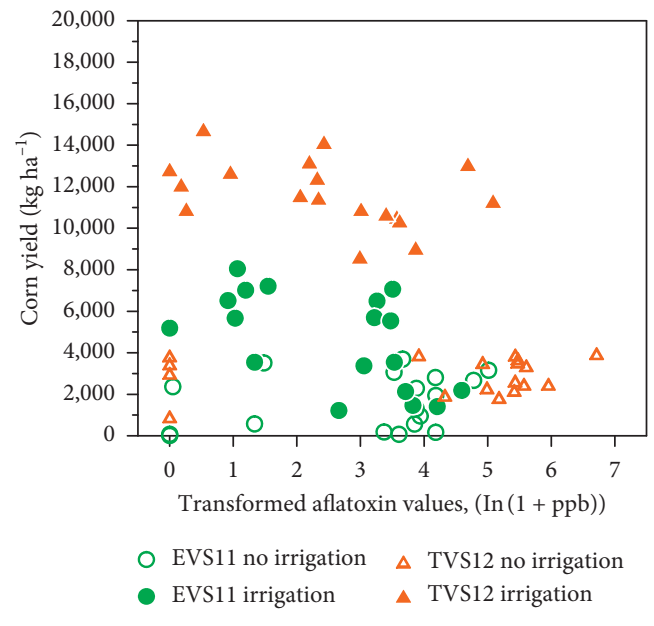

(a)

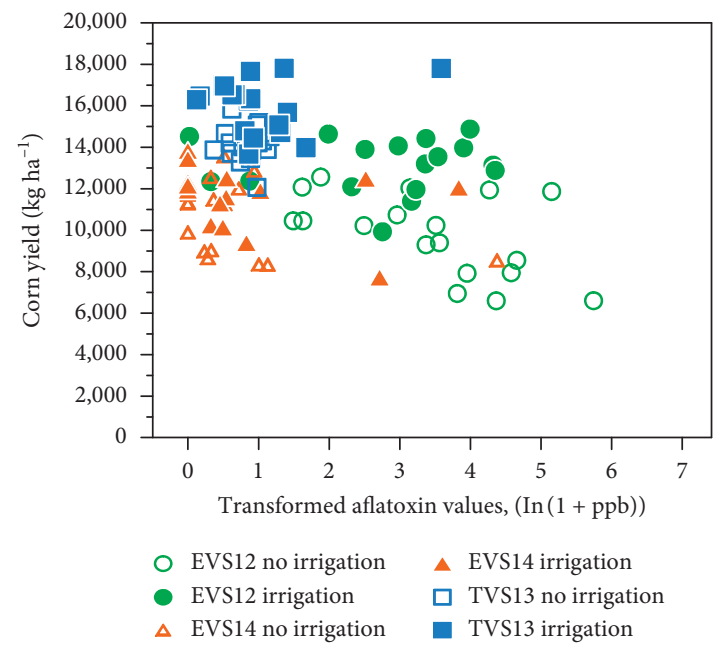

(b)

Figure 2: The relationship between corn yields and transformed aflatoxin values in the low (a) and moderate (b) moisture environments for five site-years during the 2011 to 2014 growing seasons across northern and central Alabama. Aflatoxin content (ppb) transformed as $(\ln (1+\mathrm{ppb}))$; threshold of $20 \mathrm{ppb}=3.04$ on $x$-axis.

samples and $58.3 \%$ of low-moisture plot samples had $>20 \mathrm{ppb}$ aflatoxins. Twenty-five percent of samples from irrigated corn had $>20 \mathrm{ppb}$ aflatoxin, while $44.4 \%$ of samples from nonirrigated plots were above this threshold (data not shown). The moisture environment $\times$ irrigation interaction $(P=0.0498$; Table 5$)$ was due to a significant reduction in average aflatoxin content with irrigation in low-moisture environments while irrigation did not significantly affect aflatoxin in moderate-moisture environments (Table 6). The low-moisture environment and no irrigation resulted in the highest aflatoxin contamination (Table 6) and greatest number of samples with $>20 \mathrm{ppb}$ aflatoxin.

In the low-moisture environment, aflatoxin was negatively correlated $(R=-0.26, P=0.0256)$ with yield (Table 7$)$.
Aflatoxin content was positively correlated with grain $\mathrm{N}$ concentration in both the low- and moderate- $(R>0.23$, $P<0.01)$ moisture environments (Table 7). Aflatoxin was also positively correlated $(R=0.48, P<0.0001)$ with plant height in the moderate-moisture environment (Table 7 ). These results appear to be contradictory to previous observations indicating that $\mathrm{N}$ deficits contribute to higher aflatoxin content [17]. However, most studies have only looked at $\mathrm{N}$ fertility and not $\mathrm{N}$ partitioning relative to aflatoxins. Work by Nasielski et al. [37] suggests that $\mathrm{N}$ uptake can be increased in plants grown under moisture stress, and this could explain our results. Alternatively, the low $R^{2}$ suggests substantial variability in these relationships that might indicate no biological significance. 
In the low-moisture environment, irrigation at TVS allowed consistent corn yields as aflatoxin levels increased compared to nonirrigated corn yields (Figure 2(a)). At EVS, the effect was not as pronounced between irrigation levels (Figure 2(a)). In the moderate-moisture environments, average corn yields across all site-years decreased as aflatoxin levels increased (Figure 2(b)). Aflatoxin levels remained low at TVS in the moderate-moisture environment regardless of irrigation (Figure 2(b)).

Drought and heat stress are primary factors to avoid because they contribute to aflatoxin contamination, especially during the grain filling period [17]. These conditions are prevalent in the Southeast, which increases the potential for aflatoxin contamination [38]. Early planting is used to minimize heat stress effects, while irrigation can help avoid drought stress and subsequent aflatoxin contamination [17]. The negative correlation between yield and aflatoxin contamination appears to support this argument. However, Bruns [38] reported no difference in aflatoxin levels between irrigated and nonirrigated corn. Despite the advantages of irrigation, other factors, such as adequate $\mathrm{N}$ levels, may sometimes impact aflatoxin levels [17]. Damianidis et al. [6] also reported a relationship between inseason weather conditions, primarily minimum temperature and rainfall that explained between 60 and $76 \%$ of observed aflatoxin variability. For example, in the moderate-moisture environment at EVS in 2014, aflatoxin levels remained low across the test except for one plot, despite no irrigation (Figure 2(b)). This indicates, for the growing conditions observed that site-year, irrigation was not the primary factor affecting measured aflatoxin levels. Plant density had no effect on aflatoxin levels which has been observed in other studies [6].

\section{Conclusions}

Moisture environment and/or irrigation affected all measured variables for this experiment, except test weight. Benefits of reduced soil moisture stress across these drought prone soils were evident, particularly for yield and aflatoxin contamination. Each variable was affected by the interaction between moisture environment and irrigation. Row configuration produced no effect across the variables examined in this study, except for a plant height interaction between moisture environment and row pattern, indicating that plant height increased, regardless of row pattern in the moderate-moisture environment. Plant density only affected grain $\mathrm{N}$ concentrations, but the greater grain $\mathrm{N}$ concentrations measured in the low plant densities were small ( $\sim 3 \%)$ compared to that with high plant densities. Pooled results across all site-years indicated no yield response as plant density increased, but yields were maximized with the greatest plant density in the moderate-moisture environments. The lack of response between row configurations indicates that either row configuration can be successfully adopted by Alabama corn growers, particularly if the twin-row configuration is being used for other crops in their operation.

\section{Data Availability}

The data used to support the findings of this study are available from the corresponding author upon request.

\section{Disclosure}

Mention of trade names and/or commercial products in this article is solely for the purpose of providing specific information and does not imply recommendation or endorsement by the U.S. Department of Agriculture or Auburn University.

\section{Conflicts of Interest}

The authors declare there are no conflicts of interest regarding the publication of this manuscript.

\section{Acknowledgments}

The authors would like to express their appreciation to Jeffrey Walker, Agricultural Science Technician, for his assistance with the collection of research data and acknowledge the technical support he provided that ensured success of this project. The authors would also like to recognize the assistance provided by Mr. Shawn Scott, superintendent of Auburn University's Field Crops Unit, located at the E.V. Smith Research Center in Shorter, AL, and Mr. Chet Norris, superintendent of Auburn University's Tennessee Valley Research and Extension Center, located in Belle Mina, AL. This research was supported by commodity funds from the Alabama Wheat and Feed Grains Commission and the Agricultural Research Service of the United States Department of Agriculture.

\section{References}

[1] A. M. Decker, A. J. Clark, J. J. Meisinger, F. R. Mulford, and M. S. McIntosh, "Legume cover crop contributions to notillage corn production," Agronomy Journal, vol. 86, no. 1, pp. 126-135, 1994.

[2] D. L. Karlen and C. R. Camp, "Row spacing, plant population, and water management effects on corn in the Atlantic coastal plain1," Agronomy Journal, vol. 77, no. 3, pp. 393-398, 1985.

[3] D. M. Endale, H. H. Schomberg, D. S. Fisher, M. B. Jenkins, R. R. Sharpe, and M. L. Cabrera, "No-till corn productivity in a southeastern United States ultisol amended with poultry litter," Agronomy Journal, vol. 100, no. 5, pp. 1401-1408, 2008.

[4] E. B. Lillehoj, W. F. Kwolek, M. S. Zuber et al., "Aflatoxin contamination of field corn: evaluation of regional test plots for early detection," Cereal Chemistry, vol. 55, pp. 1001-1013, 1978.

[5] R. K. Jones, H. E. Duncan, and P. B. Hamilton, "Planting date, harvest date, and irrigation effects on infection and aflatoxin production by Aspergillus flavusin field corn," Phytopathology, vol. 71, no. 8, pp. 810-816, 1981.

[6] D. Damianidis, B. V. Ortiz, K. L. Bowen et al., "Minimum temperature, rainfall, and agronomic management impacts on corn grain aflatoxin contamination," Agronomy Journal, vol. 110, no. 5, pp. 1697-1708, 2018.

[7] C. D. Dalley, M. L. Bernards, and J. J. Kells, "Effect of weed removal timing and row spacing on soil moisture in corn (Zea mays)," Weed Technology, vol. 20, no. 2, pp. 399-409, 2006.

[8] H. Blanco-Canqui, M. M. Mikha, D. R. Presley, and M. M. Claassen, "Addition of cover crops enhances no-till potential for improving soil physical properties," Soil Science Society of America Journal, vol. 75, no. 4, pp. 1471-1482, 2011. 
[9] H. Blanco-Canqui, T. M. Shaver, J. L. Lindquist et al., "Cover crops and ecosystem services: insights from studies in temperate soils," Agronomy Journal, vol. 107, no. 6, pp. 24492474, 2015.

[10] D. G. Sullivan, C. C. Truman, H. H. Schomberg, D. M. Endale, and D. H. Franklin, "Potential impact of conservation tillage on conserving water resources in Georgia," Journal of Soil and Water Conservation, vol. 63, no. 3, pp. 112-119, 2008.

[11] A. J. Franzluebbers, "Water infiltration and soil structure related to organic matter and its stratification with depth," Soil and Tillage Research, vol. 66, no. 2, pp. 197-205, 2002.

[12] J. H. Edwards, D. L. Thurlow, and J. T. Eason, "Influence of tillage and crop rotation on yields of corn, soybean, and wheat," Agronomy Journal, vol. 80, no. 1, pp. 76-80, 1988.

[13] K. S. Balkcom, R. S. Tubbs, and K. B. Balkcom, "Strip tillage implements for single and twin row peanut," Agronomy Journal, vol. 110, no. 3, pp. 1136-1146, 2018.

[14] J. R. Frederick and P. J. Bauer, "Winter wheat responses to surface and deep tillage on the southeastern coastal plain," Agronomy Journal, vol. 88, no. 5, pp. 829-833, 1996.

[15] J. E. Box and G. W. Langdale, "The effects of in-row subsoil tillage and soil water on corn yields in the southeastern coastal plain of the United States," Soil and Tillage Research, vol. 4, no. 1, pp. 67-78, 1984.

[16] G. P. Munkvold, "Cultural and genetic approaches to managing my cotoxins in maize," Annual Review of Phytopathology, vol. 41, no. 1, pp. 99-116, 2003.

[17] H. Abbas, J. Wilkinson, R. Zablotowicz et al., "Ecology of Aspergillus flavus, regulation of aflatoxin production, and management strategies to reduce aflatoxin contamination of corn," Toxin Reviews, vol. 28, no. 2-3, pp. 142-153, 2009.

[18] D. E. Farnham, "Row spacing, plant density, and hybrid effects on corn grain yield and moisture," Agronomy Journal, vol. 93, no. 5, pp. 1049-1053, 2001.

[19] J. M. Fulton, "Relationships among soil moisture stress, plant populations, row spacing and yield of corn," Canadian Journal of Plant Science, vol. 50, no. 1, pp. 31-38, 1970.

[20] H. A. Bruns and H. K. Abbas, "Ultra-high plant populations and nitrogen fertility effects on corn in the Mississippi valley," Agronomy Journal, vol. 97, no. 4, pp. 1136-1140, 2005.

[21] M. Tollenaar, "Physiological basis of genetic improvement of maize hybrids in ontario from 1959 to 1988," Crop Science, vol. 31, no. 1, pp. 119-124, 1991.

[22] D. L. Karlen, M. J. Kasperbauer, and J. P. Zublena, "Rowspacing effects on corn in the southeastern U.S.," Applied Agricultural Research, vol. 2, pp. 65-73, 1987.

[23] K. S. Balkcom, J. L. Satterwhite, F. J. Arriaga, A. J. Price, and E. Van Santen, "Conventional and glyphosate-resistant maize yields across plant densities in single- and twin-row configurations," Field Crops Research, vol. 120, no. 3, pp. 330-337, 2011.

[24] K. Balkcom, H. Schomberg, W. Reeves et al., "Managing cover crops in conservation tillage systems," in Managing Cover Crops Profitably, A. Clark, Ed., pp. 44-61, Sustainable Agriculture Network, Beltsville, MD, USA, 3rd edition, 2007.

[25] S. M. Dabney, "Cover crop impacts on watershed hydrology," Journal of Soil and Water Conservation, vol. 53, pp. 207-213, 1998.

[26] J. F. Adams, C. C. Mitchell, and H. H. Bryant, Soil Test Fertilizer Recommendations for Alabama Crops, Vol. 178, Agronomy and Soils Dept., Alabama Agric. Exp. Stn.: Auburn University, Auburn, AL, USA, 1994.
[27] H. Blanco-Canqui and R. Lal, "Crop residue removal impacts on soil productivity and environmental quality," Critical Reviews in Plant Sciences, vol. 28, no. 3, pp. 139-163, 2009.

[28] S. Mourtzinis, F. J. Arriaga, K. S. Balkcom, and B. V. Ortiz, "Corn grain and stover yield prediction at R1 growth stage," Agronomy Journal, vol. 105, no. 4, pp. 1045-1050, 2013.

[29] R. B. Mitchell, M. R. Schmer, W. F. Anderson et al., "Dedicated energy crops and crop residues for bioenergy feedstocks in the central and eastern USA," BioEnergy Research, vol. 9, no. 2, pp. 384-398, 2016.

[30] D. E. Radcliffe, R. L. Clark, E. W. Tollner, W. L. Hargrove, and M. H. Golabi, "Effect of tillage practices on infiltration and soil strength of a typic hapludult soil after ten years," Soil Science Society of America Journal, vol. 52, no. 3, pp. 798-804, 1988.

[31] D. W. Reeves and G. L. Mullins, "Subsoiling and potassium placement effects on water relations and yield of cotton," Agronomy Journal, vol. 87, no. 5, pp. 847-852, 1995.

[32] K. S. Balkcom, L. M. Duzy, T. S. Kornecki, and A. J. Price, "Timing of cover crop termination: management considerations for the Southeast," Crop, Forage \& Turfgrass Management, vol. 1, no. 1, pp. 1-7, 2015.

[33] K. S. Balkcom, F. J. Arriaga, K. B. Balkcom, and D. L. Boykin, "Single- and twin-row peanut production within narrow and wide strip tillage systems," Agronomy Journal, vol. 102, no. 2, pp. 507-512, 2010.

[34] E. Justes, B. Mary, J. M. Meynard, J. M. Machet, and L. Thelier-Huche, "Determination of a critical nitrogen dilution curve for winter wheat crops," Annals of Botany, vol. 74, no. 4, pp. 397-407, 1994.

[35] F. A. M. Tenorio, A. J. Eagle, E. L. McLellan et al., "Assessing variation in maize grain nitrogen concentration and its implications for estimating nitrogen balance in the US north central region," Field Crops Research, vol. 240, pp. 185-193, 2018, In press.

[36] I. A. Ciampitti and T. J. Vyn, "Physiological perspectives of changes over time in maize yield dependency on nitrogen uptake and associated nitrogen efficiencies: a review," Field Crops Research, vol. 133, pp. 48-67, 2012.

[37] J. Nasielski, H. Earl, and B. Deen, "Which plant traits are most strongly related to post-silking nitrogen uptake in maize under water and/or nitrogen stress?" Journal of Plant Physiology, vol. 244, 2019, In press.

[38] H. A. Bruns, "Controlling aflatoxin and fumonisin in maize by crop management," Journal of Toxicology: Toxin Reviews, vol. 22, no. 2-3, pp. 153-173, 2003. 